Portland State University

PDXScholar

\title{
Towards a Smaller Housing Paradigm: a Literature Review of Accessory Dwelling Units and Micro Apartments
}

Thomas Geffner

Portland State University

Follow this and additional works at: https://pdxscholar.library.pdx.edu/honorstheses Let us know how access to this document benefits you.

\section{Recommended Citation}

Geffner, Thomas, "Towards a Smaller Housing Paradigm: a Literature Review of Accessory Dwelling Units and Micro Apartments" (2018). University Honors Theses. Paper 515.

https://doi.org/10.15760/honors.520

This Thesis is brought to you for free and open access. It has been accepted for inclusion in University Honors Theses by an authorized administrator of PDXScholar. Please contact us if we can make this document more accessible: pdxscholar@pdx.edu. 
Towards a Smaller Housing Paradigm: A Literature Review of Accessory Dwelling Units and MicroApartments

by

Thomas Geffner

An undergraduate honors thesis submitted in partial fulfillment of the

requirements for the degree of

Bachelor of Arts

in

University Honors

and

Social Sciences

Thesis Adviser

Dr. Matthew Gebhardt

Portland State University

2018 


\section{Abstract:}

American housing has, on the average, trended larger over the last 42 years. This pattern has been challenged by a new generation of developers and builders who are embracing small construction. Accessory dwelling units and micro apartments are two typologies of small housing which have recently gained prominence. This paper finds that these two typologies have the potential to offer significant benefits to communities by providing affordable housing, decreasing the environmental impact of new construction and by providing options to diversify the homogeneous American housing stock. Several major barriers are identified which hinder the implementation of these small housing typologies, including neighborhood resistance, institutional uncertainty and hostile zoning and planning codes. Finally, a direction forward focused on increasing familiarity with small housing is presented in order to facilitate the further development of accessory dwelling units and micro apartments. 


\section{A Major Problem in the Housing Market}

In recent years, housing prices and rents have soared in cities, placing severe burdens on a large portion of the U.S. population. At the end of 2017, a full third of households spent more than $30 \%$ of their income on housing (Joint Center for Housing Studies, 2017). As prices have increased, houses themselves have gotten dramatically larger. Between 1973 and 2015 the average size of a new home in the United States grew 62\%, a gain of over 1000 square feet per home (Sparshott, 2016). Over the same time period, demographic changes have been afoot, and the average number of residents per household has steadily decreased (US Housing and Urban Development, 2015). This leads to a conundrum: house prices are rising to a point that burdens a significant share of the population, while houses themselves continue to grow larger despite smaller household sizes. Individuals are left with more housing to consume per capita but must pay royally for the privilege.

\section{A Way Forward}

Bucking the national trend, small home construction has received increased attention in the last several years. Innovative concepts for smaller living have begun to appear in multiple cities. The media has paid attention, and articles titled "Want to be happier? Live in a small home" and "Are tiny houses and micro-apartments the future of urban homes? 2 " have begun to appear in national publications. Advocates of this new trend suggest numerous benefits of building and living small, including increased affordability, sustainability, and flexibility. The millennial generation, who are prone to marry later in life and have fewer kids than preceding generations, have been suggested as the perfect consumers for smaller housing models. ${ }^{3}$ At the same time, the rise of the sharing economy and the concurrent cultural shifts have allowed urban dwellers to live with far fewer physical possessions (Infranca, 2016). ${ }^{4}$ Today, the concept of small housing might make more sense than ever before.

\footnotetext{
${ }^{1}$ (Kristian, 2017)

2 (Post, 2014)

3 Recent scholarship has explored the shifting demographics and culture of the millennial generation, and the ways that these changes have made smaller housing more appealing to this group (Chapple, Wegmann, Nemirow, \& Dentel-Post, 2011), (Urban Land Institute, 2014).

${ }^{4}$ Infranca argues that the sharing economy, which is characterized by startups including Airbnb and Uber, has revolutionized the way that people obtain goods and services. He concludes that city dwellers are able to access shared spaces (ex. Coworking studio, Airbnb) and shared possessions (ex. Tools, bikes), which dramatically reduces their need for ownership. Small urban housing can be complimented by the access to goods and services provided by the sharing economy, allowing residents to live larger than their housing might suggest.
} 
Small housing itself comes in many different forms. This thesis will explore two prominent typologies: accessory dwelling units (hereafter referred to as ADUs) and small studio apartments (hereafter referred to as microapartments). Together, these two types of construction represent Alternative Housing Typologies (AHTs)- that is to say, they differ from the predominant contemporary patterns of urban and suburban development.

ADU construction has reached record levels in several key markets, with individual and national homebuilders participating in the frenzy $y^{5}$. At the same time, several high-visibility micro-apartment projects have been completed in cities across the country ${ }^{6}$, and as of 2014, 18 micro-apartment communities were under construction, adding up to a total of 1,850 microapartment units (Urban Land Institute , 2014). The flurry of activity around AHTs is epitomized in the Housing Development Toolkit released in 2016 by the Obama White House, which calls on cities to permit ADUs and micro-apartments. The White House suggested that "Accessory dwelling units offer one solution to the [affordable housing] challenge by facilitating intergenerational living arrangements and allowing more seniors to age in place" (pp 17). On micro-apartments, the White House explained that "local zoning code changes that allow for the development of higher-density and multifamily housing, especially in transit zones, can help to alleviate some of the pressure of the growing population in many city centers" (pp 17).

\section{A Precedent}

Despite the apparent novelty of AHTs, small living is not new. Historically, analogues to AHTs have been used to meet the housing needs for a diverse group of Americans (Sage Computing, 2008), (Wong, 2015). In the early 1900s, carriage homes located in the yards of stately mansions, and alley apartments with separate entries on the rear of urban apartments, functioned similarly to modern

\footnotetext{
${ }^{5}$ Several national homebuilders now offer ADUs as an optional extra for new construction single-family residences (Macht, Developing private accessory dwellings, 2015).

${ }^{6}$ As an example, New York City recently held a city-wide development contest to create a test community of micro-apartment homes. The project has led to the creation of apartments as small as 250 square feet, with amenities including pull out pantries and convertible furniture (Carmiel, 2013).
} 
ADUs. These houses were often smaller than the primary residences that they were associated with, and they provided a home for the working poor, the household help and extended family members (SPUR Housing Committee, 2006). These secondary units were once common, until a changing culture caused them to fall out of favor. As suburbanization became the predominant pattern of development across America in the 1950s and 1960s, a desire for low-density living led most jurisdictions to ban ADUs (Sage Computing, 2008). Despite rules prohibiting their construction, ADUs have continued to be built in many expensive cities (Wegmann, Schafran, \& Pfeiffer, 2016), (Lau, 2014). The creation of these illegal units has formed an unregulated "shadow market" in which renters have little if any protection under the law (Wegmann, 2015).

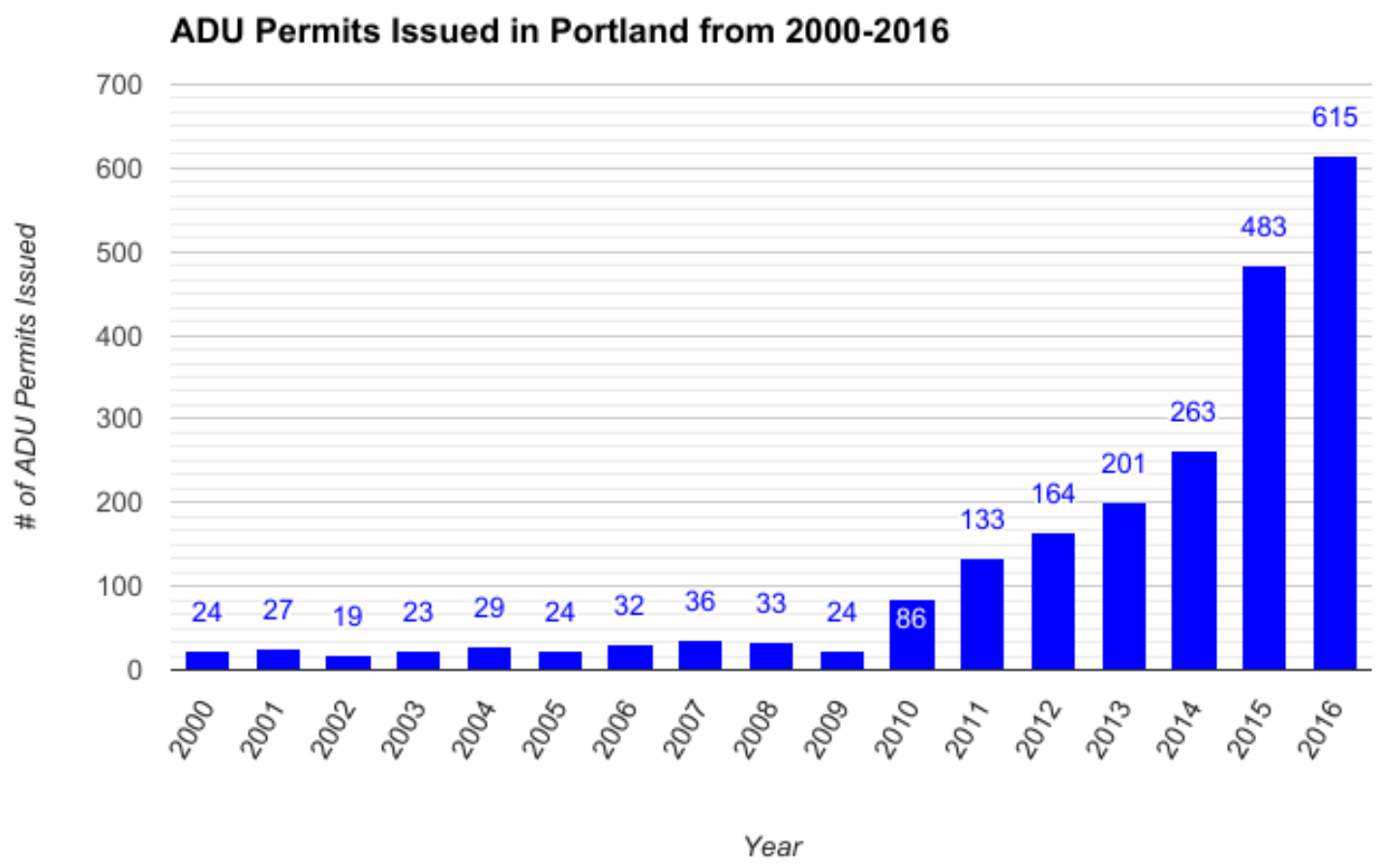

Chart created by accessorydwellingstrategies.com based on data collected by the Portland Bureau of Planning and Sustainability. Note that not all permitted ADUs are built, and some ADUs are built without a permit.

A historical precedent for micro-apartments are the Single Room Occupancy (SRO) Hotels that were built throughout American cities in the early 1900's. SROs originated as a form of housing for transient urban workers who desired a flexibility of tenure and required a location close to urban jobs. This type of housing can be defined as "partial rooms," which lack complete private kitchens and plumbing facilities, and are located within buildings containing 12 or more similar units (Overbo, Minkler, \& Liljestrand, 1991). Historian Marie Wong describes the SROs located in Seattle as following a standard typology: the first floor was commercial retail, with the potential for office space on a mezzanine floor above. The second floor and above contained "very small rooms... of residential hotel uses," double-loaded from a central corridor. Tenants were not on any sort of lease, and so were free to move at whim (Wong, 2015). Originally home to people of all class backgrounds, SROs eventually fell out of fashion, and the residents who remained in these types of housing were often the poorest urban 
citizens (Overbo, Minkler, \& Liljestrand, 1991). ${ }^{7}$ The growing stigma against SROs combined with urban renewal programs in the 1960's and 70's, resulted in the demolition of many thousands of SRO units. From 1960 to 1982, Seattle lost a full half of its downtown housing stock, including 16,000 SRO units (Werner \& Brynson, 1982). Today, gentrification continues to pick away at the small remaining inventory of SRO housing: many SROs are built on centrally-located urban land, where the value of potential redevelopment often outweighs the value of existing SRO structures. The SROs that have managed to resist demolition are often dilapidated and face a regulatory environment that makes continued operation increasingly infeasible (Overbo, Minkler, \& Liljestrand, 1991).

\section{Description of AHTs}

Modern AHTs have many similarities to their historical precedents, but also differ in key ways. To study modern AHTs, it is important to have a working definition of the different types of alternative housing that has and is being built in American cities. Due to the creative and rebellious nature of many AHT projects, finding generalizations can be challenging. However, there are some overarching patterns to AHT development which are explained below.

\section{The ADU}

Accessory dwelling unit is a planning term ${ }^{8}$ used to refer to a type of housing that shares a building plot with another home (the primary residence). Typically, the primary residence is a detached, single family home, although this is not always the case. ${ }^{9}$ According to Accessorydwellings.org, a resource for aspiring ADU builders, an ADU means "having a second small dwelling right on the same grounds (or attached to) your regular single-family house, such as an apartment over the garage, a tiny house (on a foundation) in the backyard or a basement apartment" (Brown M. J., n.d.). A more precise definition of an ADU given by Sage Computing in 2008 is as follows: "[ADUs are] additional living quarters on single-family lots that are independent of the primary dwelling unit. The separate living spaces are equipped with kitchen and bathroom facilities and can be either attached or detached from the main residence." When detached, ADUs take the form of small homes built in the yard of the primary residence. When attached, ADUs must be inside the structure of their primary residence ${ }^{10}$.

Some jurisdictions, including Vancouver BC, allow for a detached and attached ADU on one lot, which enables one primary residence to support up to two ADUs. ADUs are often built after the construction of the primary residence (many have been built in older single-family home neighborhoods), however, ADUs can be built at the same time as their primary residence ${ }^{11}$.

\footnotetext{
${ }^{7}$ A multitude of factors led to the diminishing popularity of SROs, including shifting cultural values which stigmatized tenants and rewarded homeownership, the increasing suburbanization of the middle class, and the declining need for unskilled labor. For a sociological investigation on the stigmatism against tenants, see Drier 1982.

${ }^{8}$ ADUs have different names in different communities, and are also commonly referred to as granny flats, in-law apartments, secondary units, and laneway homes.

${ }^{9} \mathrm{ADU}$ can also be built in attached townhome communities.

${ }^{10}$ Basement and garage conversions are examples of attached accessory dwelling units

${ }^{11}$ Newly constructed single-family homes with internal ADUs included can greatly reduce the cost of providing this second unit. With thoughtful architectural design, these homes can achieve an attractive appearance which does not immediately suggest the presence of an internal ADU.
} 
From a technical standpoint, an ADU must share its lot with a primary residence. At the same time, the primary residence and the ADU must be independent of one another; they must be capable of functioning as completely separate residences. Remove either the primary residence or the ADU and there will still be one unit of housing left. Functionally, this requires ADUs and their primary residence to have separate entrances, as well as separate kitchens, bathrooms and bedrooms. Residents should be able to live in the ADU without using any of the services provided by the primary residence.

Cities do not generally regard ADUs as houses in their own right; as such ADUs are often governed by different regulations than single family homes ${ }^{12}$. It can be possible to build ADUs on lots that would not allow the construction of two separate homes. In this way, ADUs can increase the density of single-family neighborhoods beyond what normal zoning would allow. ADU codes often enforce size requirements mandating that the ADU be smaller than its primary residences. Even without these regulations, ADU size is physically constrained: detached ADUs must fit in urban yards which are often small and attached ADUs must squeeze into the envelope of their primary residences. As a result, ADUs are almost always smaller than conventional single-family homes.

\section{The Micro-apartment}

The term Micro-apartment is harder to define than ADU. In academic literature, there does not seem to be consensus on terminology: some scholars and planners speak of "micro-units," others use the phrase "micro-apartments," and developers of these units often eschew any mention of size whatsoever when marketing these apartments. As explained by the Urban Land Institute, "although micro unit has no standard definition, a working definition is a small studio apartment, typically less than 350 square feet, with a fully functioning and accessibility compliant kitchen and bathroom" (2014, p. 4). It is this author's opinion that micro-apartments do not necessarily need to have full kitchens to be successful housing. Some of the first micro-apartment projects, including the Footprint Hollywood building in Portland, have only partial in-unit kitchens, complimented with communal cooking space. ${ }^{13}$

To complicate matters, it seems that the definition of micro-apartment is contextual and varies from city to city; in cities with higher average housing size, what is considered 'micro' is inevitably different than from what is viewed as 'micro' in cities with smaller forms of tenure. The city of Seattle, which now refers to micro-apartments as "small efficiency dwelling units" (SEDUs) requires these units to be no larger than 320 square feet and no smaller than 150 square feet. Seattle also requires a closet, a partial kitchen and a full bathroom (City of Seattle, 2017). Meanwhile, in San Francisco, microapartments are named "Efficiency Dwellings with Reduced Square Footage" and must "measures less than 220 square feet" (City of San Francisco , 2013). Whereas most jurisdictions share a common definition for ADU housing, this is clearly not the case where micro-apartments are concerned. In both Seattle and San Francisco, micro-apartment housing is regulated by general multifamily housing codes, and also though specific amendments which modify the base code. This makes micro-apartments subject to two different, and not always complimentary sets of regulations.

\footnotetext{
12 In fact, many cities have entire codes dedicated solely to ADU rules and regulation. A city-by-city index of ADU codes can be found at www.aduregulations.org/adu-regulations-by-city.

${ }^{13}$ In this building, individual units have a small fridge, sink, microwave and some counter space. Each of the building's 5 floors has 2 communal kitchen spaces with full sets of appliances and small dining areas. For more information, see: http://liveatfootprint.com/properties/hollywood/.
} 


\section{Benefits of AHT Development}

\section{Affordability}

Both ADUs and micro-apartments have received attention from scholars and the media as a potential source of affordable housing ${ }^{14}$. The San Francisco Bay Area Planning and Urban Research Association (SPUR) considers ADUs and micro-apartments to be "affordable by design" (Karlinsky, Szambelan, \& Wang, 2017, p. 16), ${ }^{15}$ and the Seattle-based Sightline Institute calls micro-apartments "an important niche in terms of providing market-rate affordable housing" (Neiman, 2017).

Using survey data in suburban New York, Rudel (1984) found that ADUs rented for $35 \%$ less than other non-ADU housing. More recently, Brown (2014) used survey data in conjunction with the Oregon Department of Environmental Quality to examine ADU rents in Portland, Oregon. He found that $13 \%$ of the ADUs surveyed were leased free of rent, and that another $5 \%$ were rented for less than $\$ 500 /$ month, which was far below market rents in Portland at the time. These results also found that a large portion (as much as $25 \%$ ) of ADUs in Portland are occupied by friends or family members of the homeowner (Brown M. J., 2014). Due to the presence of these extremely low-cost ADU rentals, the mean ADU rent was $\$ 753$, compared to a mean comparable apartment rent of $\$ 778$, a difference that was not found to be statistically significant. A study by Wegmann and Chapple (2012) found that the average ADU in San Francisco was affordable to residents earning $62 \%$ of area median income (AMI), whereas other units were on average affordable to residents earning $68 \% \mathrm{AMI}$. This study concluded that ADUs were an important reservoir of affordable units, and attributed their lower rents to their small size, lack of certain amenities (i.e. dishwashers) and likelihood that utility costs were shared with the primary residence. The variability between different studies suggests a need for further research exploring ADU rental rates. This task is more difficult than it appears because there is a lack of accessible data on single family home rental rates, which caused Brown (2014) to compare ADU rental rates to studio or one-bedroom apartment rental rates. Another challenge faced by Wegmann and Chapple (2012) is the lack of a database of homes with ADUs, which required the two authors to send out surveys to random homeowners, hoping to identify properties with ADUs.

ADUs can have indirect financial impacts for both residents and homeowners. For example, ADUs can provide a subsidy to the ADU homeowner by allowing the ADU rent to offset their mortgage payment (Wegmann \& Chappel, 2012). For households who struggle with the cost of their mortgage, adding an income stream in the form of an ADU can make their home purchase more affordable. ADUs can also allow owners to provide a dwelling with reduced rent to friends and family members. For example, owners with aging parents could allow their parents to move in to their ADU for below-market rent. Along the same lines, parents with an ADU on their residence could allow their adult children to live in the ADU. Both options provide flexibility to the owners and the renters.

The rents charged for micro-apartments have not been studied as extensively as those of ADUs. These projects are still only a tiny fraction of the total apartment stock, and due to their recent re-

\footnotetext{
${ }^{14}$ For examples of media coverage relating to affordability see (Templeton, 2017) and (Valhouli, 2016)

${ }^{15}$ Housing that is affordable by design has low enough development cost that builders can still make a profit while providing the housing at affordable rates. This is opposed to housing that is "affordable by subsidy," which requires subsidy money from non-profits and/or cities to buy down the cost of development. The nationwide shortage of subsidy money for affordable housing development is a large enough issue to merit another paper entirely.
} 
emergence, empirical research on micro-apartments is limited. Regardless, there is a well-documented trend that suggests that smaller apartments rent for less in gross than larger units. The trend is illustrated in the graphic below, which was prepared by the Sightline Institute using data from Dupe + Scott, a Seattle apartment appraiser and consultant. In the chart, unit size is plotted on the X-axis, with rents on the $\mathrm{Y}$-axis.

Figure 1: Seattle rents in properties with 20 units or more, Fall 2016 survey

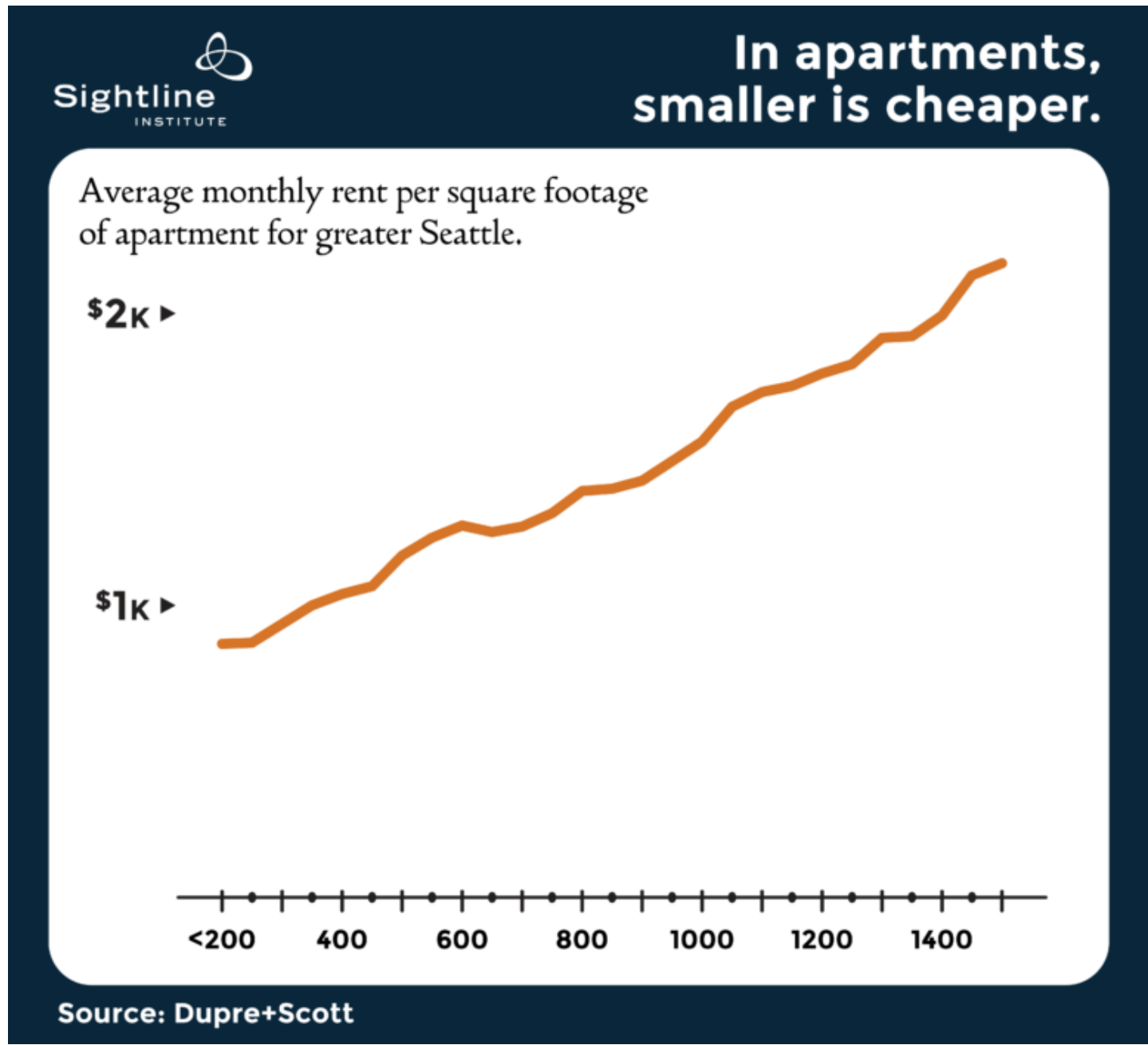

Although micro-apartments have higher per-square-foot rents (Urban Land Institute , 2014, p. 15), because these units have dramatically less square footage than conventional apartments, their gross rent is lower. Micro-apartment developers are able to charge less for rent because these projects economize on land and reduce per-unit construction $\operatorname{costs}^{16}$. It is also possible that micro-units have lower average operating costs per unit than conventional studios and other larger units, which further decreases the rent required to support a project (Stern \& Yager, 2018).

\footnotetext{
${ }^{16}$ Estimates of total development costs are higher per building (assuming equivalent square footage) for microapartments than for conventional studios. However, the additional units made possible in the micro-apartment projects leads to a lower per unit development cost. If shared kitchens are utilized, construction costs per unit decrease even more. For a detailed cost breakdown of micro-apartments, see Stern \& Yager, 2018
} 
The widespread adaptation of AHTs could lower rents citywide by increasing the total supply of housing. Following rudimentary economic laws, when population grows faster than housing is constructed, housing costs will rise. The highest-cost metropolitan areas have limited new housing supply that cannot keep up with population growth and in-migration ${ }^{17}$. This positive effect of home construction on housing affordability is well documented ${ }^{18}$.

It is also important to consider the spatial implications of AHT affordability. AHTs might very well be the cheapest option in otherwise high-cost neighborhoods. Sage Computing suggests that ADUs can help increase housing options for lower income renters by providing smaller, more affordable units in expensive single-family neighborhoods (Sage Computing, 2008). The same trend applies to microapartments, many of which are built in high-rent, high-amenity urban neighborhoods, such as Capitol Hill, Seattle. Both ADUs and micro-apartments have the possibility to give these residents access to neighborhoods that they could not otherwise afford.

In expensive cities like Seattle, Portland and San Francisco, geographical constraints on available land work to limit the potential supply of new housing (Gyourko, Mayer, \& Sinai, 2013). AHTs can unlock additional construction potential on this limited land. ADUs are able to be built in existing neighborhoods, on lots with existing housing. In Portland alone, it is estimated that there are 70,863 tax lots prime for ADU development (Gleim, 2017). As a result, more than 70,000 homes could be built on existing city land. Construction of ADUs on less than $10 \%$ of these lots could theoretically meet the total rental demand through 2019 in the Portland metro ${ }^{19}$. Micro-apartments can similarly infill urban areas with a denser pattern of development than conventional apartments, therefore making better use of the limited supply of land to provide housing.

\section{Increased Density at an Incremental Scale}

Density has long been recognized as an essential component of vibrant and successful cities. As early as 1961, pioneer urban theorist Jane Jacobs wrote about the importance of density in maintaining social order and supporting neighborhood commerce (Jacobs, 1961). ${ }^{20}$ Economists have studied the spillover effects of urban density, concluding that close proximity to other workers increases average

\footnotetext{
${ }^{17}$ Portland and San Francisco are examples of markets where demand has far outstripped supply. Economists have found that the City of Portland is only on track to meet $46 \%$ of rental housing demand, and $8 \%$ of for-sale housing demand through 2019 (Office of Policy Development and Research, 2016, p. 2). In San Francisco, where demand has been estimated at 3,000-5,000 units annually, construction has produced an average of only 1,500 units over the last 20 years (Gabbe, 2014). For more information on the geographic differences in home pricing, see (Gyourko, Mayer, \& Sinai, 2013). Here, the authors lay out a framework for understanding high-demand, lowhousing-supply cities, wherein housing itself functions as a luxury good.

${ }^{18}$ A 2016 brief by the California Legislative Analyst's Office summarizes the existing research, concluding that California should act to encourage private home building in order to reduce housing costs (Taylor, 2016).

${ }^{19}$ Based upon HUD (2016) estimates of total housing needs in the Portland Metro.

${ }^{20}$ Jacobs suggested that a critical mass of people was necessary to maintain 'eyes on the street' watching for potential criminal activity. In addition, she recognized that density enabled the development of the unique and niche shopping, dining and entertainment choices that make cities interesting. In the 1960s, Jacobs' theories on density ran counter to the consensus of academics and urban planners, who campaigned against density as a marker of filth and decay. Needless to say, the planning mainstream has since come to recognize the wisdom in Jacobs' theories, and today, density is widely celebrated by governments and the planning orthodoxy. For more on the benefits of density, see (Kackar \& Preuss, 2003).
} 
productivity per worker. Significantly, this boost to productivity is greater the larger the reserves of human capital in the metropolitan area; the larger the city, the bigger the benefit conferred by density (Abel, Dey, \& Gabe, 2011). Higher density can also increase the viability of public mass transit and can support the creation of walkable neighborhood retail (Kackar \& Preuss, 2003). This in turn results in a more environmentally friendly city, where residents are not as dependent on the automobile for their daily trips.

AHTs offer a direct method to increase urban density, often in ways that can prevent disruption to existing neighborhoods. Due to the fragmented neighborhood fabric of many residential subdivisions, the provision of increased density is difficult using conventional development strategies ${ }^{21}$. Adding multifamily housing, where each lot supports multiple dwelling units would require the destruction of existing residences and would be hindered by the small suburban lot sizes. Even if a large accumulation of land is possible, many single-family neighborhoods are rigidly zoned to prevent multifamily construction in the first place. If large-scale apartment housing is built in a neighborhood that is primarily single-family in character, the visual dissonance between the new construction and the old neighborhood is apt to draw neighborhood controversy 22 .

The ADU can circumvent almost all of these concerns. ADUs can be constructed one at a time on existing home sites without requiring demolition. ADUs can be permitted by cities in zoning that would not allow for traditional multifamily construction. Finally, ADUs can address some of the common neighborhood concerns about density. ADUs often blend in to the existing fabric of the neighborhood, allowing for increased population mass without vastly changing the appearance of a community. Introducing ADUs into single-family neighborhoods at an incremental pace could be a strategy for overcoming neighborhood opposition to new housing (Brinig \& Garnett, 2013).

In neighborhoods that already play host to multifamily housing, micro-apartments can allow developers to further increase density ${ }^{23}$. This is especially beneficial in areas of fragmented land ownership, where no owner has more than a small plot of land (for example single family neighborhoods on the border of the urban core). In already-dense neighborhoods, micro-apartments can allow the provision of even higher density, and for neighborhoods that are in the process of densifying, micro-apartments can augment this trend.

\footnotetext{
${ }^{21}$ Conventional apartment development is often dependent on developers gaining control of large, unbroken land parcels which is not always possible in residential subdivisions, which consist of many small land parcels held by many disparate neighbors.

${ }^{22}$ Regardless of the potential benefits of density, the topic is fraught with controversy. Many well-meaning neighborhood groups fight against new construction on the basis that the resulting density will increase traffic and decrease calm. Although there are certain negative externalities associated with high concentrations of population, it is the belief of this author that much of the opposition to density is based on stereotypes, rather than its actual negative effects. As noted on multiple occasions by Jacobs (1961), the most popular urban neighborhoods are often the densest.

${ }^{23}$ The Footprint Hollywood project in Portland (previously referenced) fits 58 units on to a lot that is only 4,775 square feet, equating to a density of 532 units per acre. For comparison, the Burnside 26, a conventional apartment building built during the same time period as Footprint Hollywood consists of 135 units on 29,121 square feet, achieving a density of only 201 units per acre. If Footprint Hollywood had instead been built to contain conventionally sized units, it would fit barely 22 apartments (portlandmaps.com) (costar.com).
} 


\section{Lower Greenhouse Gas Emissions}

AHTs also promise to offer significant environmental benefits to communities. Small housing is inherently energy efficient to build, as it requires less upfront resources to build (US Housing and Urban Development, 2015). The advantages of small construction do not stop after construction. Buildings are responsible for a significant portion (36\%) of total energy usage in the United States (Environmental Protection Agency, 2013), and as houses get larger, so too does the amount of raw energy required to heat and cool them (U.S. Energy Information Administration, 2012). It is well documented that small housing requires less energy during ongoing operation, even without environmentally friendly features like triple-pane windows. ${ }^{24}$

AHT housing brings increased density to neighborhoods, as explored in the previous section. This density can help to reduce automobile dependence, contribute to walkable cities, and foster public transportation. Multiple studies have shown that ADU residents are less likely to own cars than residents in other building types (Brown M. J., 2014) (Chapple, Wegmann, Nemirow, \& Dentel-Post, 2011), and testimonials from developers of micro-apartments seem to suggest the same trend for these units $^{25}$. Dense regions are correlated with a higher level of public transportation usage, and a larger share of trips completed on foot (Ewing, Pendall, \& Chen, 2003). It is also possible that AHTs can promote car sharing infrastructure (Chapple, Wegmann, Nemirow, \& Dentel-Post, 2011). In a dense city, even the trips that do require a private automobile are likely to be shorter. All of this can help contribute to a world where cars are less necessary.

Finally, because AHTs are primarily built in already developed regions, they protect against sprawl. Building an AHT on an urban lot allows housing construction without the clearing of forest land, as is required for new subdivisions on the urban fringe. This also allows for the AHT to take advantage of existing city infrastructure, saving the energy cost of infrastructure construction. The benefits of infill development are numerous and have been recognized by the U.S Environmental Protection Agency (2014).

\section{Increased Housing Diversity}

Today, American renters are more diverse than in past generations. The changes in renter populations suggest a need for more flexibility in new housing construction, and AHT housing offers builders the potential to meet the needs of a broader spectrum of the population. As household sizes continue to shrink, the need for large 2 and 3-bedroom houses and apartments will decline. With young Americans getting married later and living alone at greater frequency (Been, Gross, \& Infranca, 2014), the desirability of AHTs is likely to increase.

\footnotetext{
24 See Pitt 2013 for more detail on the energy savings provided by compact living.

${ }^{25}$ According to developer Jim Potter, who has built micro-apartments in Seattle and Portland, only $10-20 \%$ of the residents in his communities own cars (Njus, Micro-apartments of less than 200 square feet coming to Portland, 2013).
} 
When asked, $25 \%$ of current renters in conventional apartments expressed an interest in microapartments, suggesting that there is potential untapped demand for this type of unit (Urban Land Institute , 2014). AHTs can provide the option of living alone to residents who would otherwise be forced to offset the high cost of housing with roommates. Finally, by building micro-apartments for urban singles, some of the housing demand of these renters can be absorbed, removing the pressure they place on larger family units (Gabbe, 2014).

The population of adults over 65 years old is expected to more than double between 2010 and 2050 (Lipman, Lubell, \& Salomon, 2012). For the elderly, ADUs have been explored as a possible solution to allow owners to "age in place" (Chapman \& Howe, 2001) ${ }^{26}$. In a report co-sponsored by the AARP, the Center for Housing Policy has called upon cities to build more ADUs and multifamily housing given the suitability of these types of housing to elderly residents (Lipman, Lubell, \& Salomon, 2012). ADUs in particular can help facilitate multi-generational living situations, where adult children and their parents can share a housing lot, but still retain privacy (Menard, 2016).

\section{Challenges to Implementation}

With all the potential benefits of AHTs, it might come as surprise that these types of housing are still scarce, representing only a small portion of the total housing construction in American cities. For example, the City of Portland reports receiving approximately 200 ADU permit requests in 2013. (City of Portland, n.d.). Even if all 200 permits were granted, this number pales in comparison to the 2,992 multifamily building permits granted by the city in the same year (Strabic, 2016) ${ }^{27}$. Data on microapartment construction is hard to find, and it appears that this type of housing is still a niche market in major cities. The City of Seattle, which led the modern resurgence of micro-apartments, had produced only about 3000 such units by 2014 (Solovitch, 2014). Developers in other cities, including New York and San Francisco have just started to experiment with this type of housing in the last few years, and have undertaken small test programs. ${ }^{28}$ The lethargic pace of ADU and micro-apartment development can be explained by a myriad of factors which challenge these types of development. First, as a new product type for developers, AHTs have faced skepticism from the institutions that support real estate development. AHTs have also garnered controversy from neighborhood groups and city planners. Finally, in many cases, city regulatory policy hinders or completely forbids the development of AHTs.

\footnotetext{
${ }^{26}$ There are several significant challenges to housing the elderly, including disability and other health challenges (resulting in mobility limitations), lack of income, a desire to remain in their current homes and a need for services. The full extent of these challenges is outside of the scope of this paper but has been studied extensively. For more information on elderly housing preferences see (Chan \& Gould, 2017). For the challenges of housing elderly populations, see (Lipman, Lubell, \& Salomon, 2012), and for the inadequacies of the existing housing stock for this population, see (Keenan, 2010).

${ }^{27}$ This is in a city that has been on the forefront of the ADU movement in the USA. In 2010, Portland implemented several significant policy changes targeted at increasing ADU construction. Prior to the 2010 overhaul, the city saw approximately 30 ADUs built each year (City of Portland, n.d.). By comparison, Seattle, which only legalized ADUs in 2010, only saw 153 permitted over the next 5 years (Young, 2015). This number is roughly equivalent to Portland ADU construction prior to 2010, although the population of the Portland metro is significantly smaller.

${ }^{28}$ The first such project in New York City, which features 55 apartments between 260 and 360 square feet opened in June 2016 (Green, 2016). Similar projects in San Francisco seem to be produced primarily by one developer, Panoramic Interests. Panoramic has completed 4 micro-apartment projects in San Francisco by 2018, with 2 more on the way and a third under construction in nearby Oakland (Panoramic Interests, n.d.).
} 


\section{Unfamiliarity Leads to Caution}

In many ways, AHTs represent an untested frontier. Despite advances in the field, there is a general lack of institutional knowledge about AHTs, a point that is hindering the development of more such projects (Macht, 2017). Real estate development is capital intensive, and often relies on funding from a variety of different sources, including banks and development equity funds. These large financial institutions are bureaucratic and risk adverse, making them slow to react and adapt to new development typologies.

This particular tendency of banks impacts both ADU builders and homebuyers considering homes with existing ADUs. The challenge of securing construction loans to finance ADU construction has been recognized by multiple scholars as a point of friction (Been, Gross, \& Infranca, 2014) (Wegmann, 2015). The lack of financing options can relegate ADU owners to the wealthy few who can afford to build these units out of pocket. In the re-sale market, a well-qualified homeowner seeking to buy a house with an ADU will quickly run into difficulty. Whereas an investor buying an apartment building would be able to borrow against the expected income stream of the building, ADU buyers are often unable to borrow against the expected rental income of the ADU (Wegmann, 2015).

While it is easy to blame the banks alone for bottlenecking ADU finance options, banks themselves do not hold full responsibility. Many residential banks sell the loans that they originate on the secondary market. The Federal National Mortgage Association (Fannie Mae) and The Federal Home Loan Mortgage Corporation (Freddie Mac), control this secondary market by securitizing mortgage bundles. Both Fannie Mae and Freddie Mac have different definitions for ADU-type units, and both ascribe them relatively little value, which inhibits the sale of ADU loans on the secondary market (Macht, 2015). The Federal Department of Housing and Urban Development (HUD), which administers the FHA mortgage insurance program, has its own third set of definitions and considerations which lenders must adhere to if they wish to receive FHA insurance (Brown \& Watkins, 2012). Finally, banks are dependent on appraisers to validate loan amounts, and the appraisal of ADUs is poorly understood. Altogether, the institutions of Fannie Mae, Freddie Mac, and HUD encourage lenders and appraisers to value ADUs in an extremely conservative fashion (Brown \& Watkins, 2012) which can prevent builders from recapturing their investment upon the sale of their properties.

As a further confounding factor, most ADUs are built directly by homeowners, the majority of whom have little to no development experience. As novice developers undertaking their first project, lack of experience can lead to difficulties when navigating the permit process and assuring sound construction. Based on survey data, a full $70 \%$ of ADU owners experienced unanticipated events when building their ADU that led to "delays and cost increases," perhaps a symptom of developer inexperience (Chapple, Wegmann, Mashhood, \& Coleman, 2017, p. 22). Many contractors also lack ADU experience, evidenced by the large number of ADU owners (24\%) who wished they had access to professionals with ADU experience when building their ADU (ibid). For large contractors, building a single ADU can represent a project too small to be worth the time, especially in hot markets where construction workers are in high demand.

Micro-apartment development necessarily takes place at a larger scale than ADU development; micro-apartment projects are built by professional developers and often consist of dozens of units. Despite their larger scale, these projects are equally hindered by their novelty. As recently as 2014 , the Urban Land Institute recognized that institutional development capital is wary of micro-unit projects, 
perceiving them as a riskier investment than conventional apartments. The micro-apartments which have been built have often required developers to seek innovative financing sources, or to design buildings with only a small share of micro-units. ${ }^{29}$ As more micro-apartment projects are completed and stabilized, hesitant financiers might warm up to this building type. Until then, it is likely that microapartments will continue to be fringe projects built by creative and well-capitalized developers.

\section{The Challenges of Appraisal}

Prior to issuing a loan on a property, a bank will order an appraisal from a licensed third-party professional. The appraiser will consider numerous factors before finally arriving at a value which they believe represents the market value of the property. If the property appraises lower than the value of the loan, the bank will either refuse to issue the loan, or will require additional money down prior to funding. This process gives the appraiser great power in determining the value of property.

To understand the difficulty in the appraisal of property with an ADU, it is important to consider the difference in appraisal methods between residential and commercial property. Residential property is appraised with a Sales Comparison approach, where the property is compared to other recent sales on a like-kind basis, with adjustments made for differences in fit and finish between properties. Commercial property which produces income is valued on an Income Capitalization approach, where the present value is calculated based off an anticipated stream of future payments (rents).

ADUs are a residential property that also have the potential to generate rents. As such, it is uncertain which approach should be used to value ADUs. As noted by Brown and Watkins (2012), there is "almost no formal writing" on the topic in peer-reviewed journals. The sales comparison approach is confounded due to a lack of comparable sale; homes with ADUs represent such a small share of the singe-family housing market, and ADUs themselves vary so considerably, that appraisal using this method is extremely challenging. Meanwhile, using an Income Capitalization method might accurately reflect the value of the property to a long-term investor, but overstate the price that the open market will bear. For example, a pilot test of an Income Capitalization approach carried out on 14 properties with ADUs suggested values that were on average between $7.2 \%$ and $9.8 \%$ higher than actual sales prices (ibid).

As ADUs continue to grow in popularity, it will be necessary for additional research into possible appraisal methods for this type of housing. A recommended first step would be the collection of a comprehensive database of ADU home sales. For a thorough treatment of ADU appraisal, see Brown and Watkins (2012) "Understanding and Appraising Properties with Accessory Dwelling Units."

\footnotetext{
${ }^{29}$ One of Panoramic Interest's large micro-apartment projects in San Francisco was able to qualify for conventional financing, but the project was already 50\% preleased by California College of the Arts to be used as student housing. As another example, The Flats in Chicago, developed by Cedar Street Development, is a 350-unit project, of which approximately $15 \%$ are micro-apartments, ranging from 275 to 300 square feet. One can assume that a project with only $15 \%$ micro-units is less likely to lead to investor hesitance (Urban Land Institute , 2014).
} 
Still unexplored is the sale of micro-apartment buildings. Many developers eventually sell their projects to outside investors, real estate investment trusts (REITs) or other large investment funds. It is uncertain how micro-apartment projects will fare on this secondary market. Large real estate funds without experience in micro-apartments might be hesitant to take a risk expanding their portfolio. Also, because the economics of small apartment communities are different than those of conventional apartments, seasoned investors might not know how to properly manage these projects to maximize their returns (Urban Land Institute , 2014). At the time of writing, this author is aware of only two sales of micro-apartment buildings: The Freedom Center Apartments in Portland; and the Whitley House in Los Angeles ${ }^{30}$. Meanwhile, the two firms responsible for the majority of micro-apartment construction in Seattle and Portland (Calhoun Properties and Footprint Development) both build, own and manage their projects, and appear to be positioned for a long-term hold strategy. It is likely that a more substantial record of micro-apartment sales will help encourage skeptical developers to embrace this new typology.

\section{Unfamiliarity Leads to Opposition}

The development of ADUs and micro-apartments alike has garnered substantial controversy from neighborhood groups and urban planners. The opposition spans from general fears of increased density and its associated externalities to a complete rejection of the concept of small living. Micro-apartments seem to attract more negative attention, perhaps due to their higher visibility and larger project size. The opposition to ADUs is often abstract, with detractors fighting for codes that prohibit these units from being built in the first place. With micro-apartments, opposition occurs in the abstract, but also crystalizes around specific projects, which provide easy targets for upset neighbors to protest.

ADUs are primarily built in single-family neighborhoods where the proportion of homeowners is likely to be high and the proportion of renters is likely to be low. In this context, opposition to ADUs is often tied to fears of decreased property values (Brinig \& Garnett, 2013) ${ }^{31}$. ADUs, which increase density are seen by some as increasing "the likelihood of the negative externalities associated with density," which include the loss of parking resources and potential for strain on public resources, including schools and roads (ibid). The importance of parking as a concern is shown by Wegmann and Chappel (2012), who found that the most common opposition to ADUs was based on parking. Arguments with a more exclusionary flavor include the suggestion that ADUs will bring undesirable, lower-income residents into what are otherwise expensive neighborhoods (Friedrich, 2004). It is often neighborhood associations that mobilize to resist ADUs, as these groups bring together concerned homeowners and amplify their voice to city council. ${ }^{32}$

\footnotetext{
30 The sale of the 148-unit Freedom Center (which occurred May 2017) was not without difficulty, and the building failed to sell the first time that it was marketed. During its time on the market, the Freedom Center was represented by 3 different brokerages, suggesting that the sale of this type of building requires specific expertise (Davis, 2017). The Whitley House, which contains 70 micro units and 30 one-bedroom units, was reportedly sold to a private investor in 2014 (Vincent, 2014).

${ }^{31}$ Property values have been and continue to be a major motivator of restrictive land use policies. Although it is easy to critique these policies as classist and elitist, it is understandable that homeowners (whose home is often their biggest asset) would want to protect their investment.

${ }^{32}$ As an example, see Whorton 2009, accessible at http://www.laurelhurstcc.com/issues/Housing/DADUs.htm
} 
To see micro-apartment opposition, one can look at the local news. Some recent headlines from Seattle include: Microhousing Opponents: They Shouldn't Be Allowed to Live Like That, Opposition Growing to Seattle Micro-Apartment Trend, and The Fight Against Small Apartments. ${ }^{33}$ All three articles were published from 2013-2014 during the height of the micro-apartment boom in Seattle. In Portland, one can read articles titled: Micro-apartments Create a Macro-Problem for Portland Parking; and Tiny Spaces Put Squeeze on Parking ${ }^{34}$. The major recurring concerns raised about micro-apartments can be classified into the following groups: health and safety concerns; parking concerns; fears of transient populations; and complaints about the rents of these units. Empirical research and experience with micro-apartments suggest that many commonly raised fears of this type of housing are unwarranted (Neiman, 2017). Table 1 breaks down the fears and the reality in the micro-apartment battle.

Table 1: Common micro-apartment concerns and possible solutions

\begin{tabular}{|c|c|}
\hline Concern & Solutions \\
\hline $\begin{array}{l}\text { Micro-apartments are too small for human } \\
\text { health, and present conditions that are not fire- } \\
\text { safe }\end{array}$ & $\begin{array}{l}\text { The National Healthy Housing Standard does not } \\
\text { require units to be larger than a certain size }{ }^{35} \text {. } \\
\text { People in vibrant cities across the world (e.g., } \\
\text { Tokyo, Paris) are accustomed to small living. } \\
\text { Micro-units have fire sprinklers and are required } \\
\text { to follow the same fire standards as other } \\
\text { multifamily buildings, minimizing fire risk. }\end{array}$ \\
\hline $\begin{array}{l}\text { Micro-apartments do not provide parking, and } \\
\text { will clutter existing street parking }\end{array}$ & $\begin{array}{l}\text { Developers suggest that a small portion of micro- } \\
\text { apartment residents own cars (between 10-20\%). } \\
\text { This assertion is not backed by empirical data, so } \\
\text { survey research should be undertaken to better } \\
\text { understand whether cities need to require on- } \\
\text { site parking for these projects }\end{array}$ \\
\hline $\begin{array}{l}\text { Micro-apartments will be home to transient and } \\
\text { undesirable populations and will deteriorate into } \\
\text { slum-like conditions due to substandard } \\
\text { construction }\end{array}$ & $\begin{array}{l}\text { This fear likely amounts to classism and a distrust } \\
\text { of those with lower-incomes. Holden (2013) } \\
\text { notes that the micro-projects in Seattle are often } \\
\text { well-maintained and are built by developers who } \\
\text { intend to hold and operate the projects into the } \\
\text { long run. Many of the residents are young } \\
\text { professionals, not transients. Conducting tours of } \\
\text { existing micro-apartment projects and } \\
\text { introducing opponents to the residents of these } \\
\text { projects might help to alleviate this unfounded } \\
\text { anxiety. }\end{array}$ \\
\hline
\end{tabular}

\footnotetext{
${ }^{33}$ Erika Barnett for Seattle Met; The Associated Press for The Oregonian; and Dominic Holden for The Stranger respectively. All three articles chronicle the fight taking place at neighborhood meetings and in city hall over the continued proliferation of micro-apartments.

${ }^{34}$ Elizabeth Hovde for The Oregonian and Peter Korn for The Portland Tribune, respectively.

${ }^{35}$ The National Healthy Housing Standard (Benjamin \& Vernon, 2014) collects empirical research to issue guidance on a myriad of housing factors that are important to human health. The Standard, most recently published in 2014, has no information on total unit size, although it suggests that individual rooms be 70 square feet or larger (modern micro-apartments are often twice this size or larger). The full text of these guidelines can be incorporated by cities seeking to regulate micro-apartment projects, without sacrificing the small unit size that makes microapartments micro.
} 
Micro-apartments are more expensive on a per square foot basis and therefore represent bad value for tenants. This will lead apartment owners to increase the rent of conventional apartments
While micro-apartments do have higher persquare-foot rents than conventional apartments, they have lower marginal monthly rents than comparable new studios due to their small size (Urban Land Institute, 2014). Many of these units also include utilities and internet, further decreasing costs to residents. Smaller units have higher per square foot rents in general, so micro apartment rents will not affect the per square foot costs of neighboring rentals (Holden, 2013).

What is causing the opposition to micro-apartments despite the unfounded nature of the many complaints? It is a common paradigm that neighborhood change is likely to create opposition and as a new type of housing, AHTs represent a change from more traditional housing typologies. Some tenant advocates object to micro-housing on humanitarian grounds, fearing that these units will set a bad precedent and eventually allow for the return of tenement housing that is of substandard quality (Wollan, 2012). For planners, a lack of experience with these types of projects might also lead to opposition (Macht, 2017). More scurrilous claims about transient populations are part of a broader cultural discourse about renters that is not limited to micro-housing (Drier, 1982).

While it might be convenient to dismiss the concerns of neighborhood groups and planners as wholly irrational, writing off the opposition in this way is likely to "In most cities, whenever there's a period of massive growth, the political impulse is to clamp down" (Solovitch, 2014, p. 2) breed resentment and further entrench oppositional viewpoints. Contained within the common threads of opposition are legitimate problems of parking and the effects of high density. The City of Seattle presents a cautionary case study of the challenges of development without citizen input: the original developers of micro-apartments in Seattle were able to build high density micro-units by taking advantage of code loopholes. This bypassed traditional building review required for large multifamily projects, which created anger amongst neighbors who felt duped. ${ }^{36}$ Instead, a slower process which involves neighborhood input might have more success. In New York, the city held a contest titled "adAPT NYC," in which multiple developers bid to have a chance to build the first microapartment project. An approach akin to this might generate more neighborhood buy-in, but also slows the process of creating micro-housing when this housing is desperately needed ${ }^{37}$. Perhaps a hybrid program could be deployed, where in a city authorizes a certain number of test projects to be built simultaneously by multiple developers across the jurisdiction.

\section{Unfamiliarity Leads to Regulatory Barriers}

One of the most salient barriers to AHT development is the patchwork of local land use regulations prescribing what can and cannot be built. In 1926, the Supreme Court affirmed the right of cities to use land use zoning to segregate different uses. Since then, the courts have continually upheld

\footnotetext{
${ }^{36}$ See Solovitch 2014 for testimony to this effect.

${ }^{37}$ The adAPT NYC contest was announced in 2012 and building occupancy did not start until late 2016.
} 
the right of local jurisdictions to control what gets built and where (Geffner, 2017). Today, almost all major cities have complicated zoning codes which dictate developers' ability to build AHT housing. The specific types of regulations that most affect ADUs and micro-apartments are density regulations (Been, Gross, \& Infranca, 2014), parking requirements (Chapple, Wegmann, Nemirow, \& Dentel-Post, 2011) (Gabbe, 2014), lot size, unit size and owner occupancy limits (Been, Gross, \& Infranca, 2014) , open space mandates and unit mix regulations (Gabbe, 2014).

Parking requirements can render development of AHTs unfeasible by requiring a certain provision of off street parking spaces. A 46-city survey in the Pacific Northwest conducted by the Sightline Institute and the Oregon Department of Environmental Quality found that 36 of the subject cities had off-street parking requirements for ADUs (Durning, 2013). It is not always possible to build offstreet parking for ADUs due to site constraints. In the cases that off-street parking is possible to build, it represents a significant cost premium (ibid). The same is true for the construction of micro-apartments, where parking mandates have been associated with an additional cost of between $\$ 25,000-\$ 50,000+$ per space ${ }^{38}$.

Lot and size limits and owner occupancy requirements can impact ADU development specifically. Codes relating to lot size can require that ADUs only be built on larger than average singlefamily lots and codes that relate to unit size can prevent some homeowners from building reasonably sized ADUs (Been, Gross, \& Infranca, 2014). Owner occupancy requirements mandate that the owner of the primary residence must live on site, or in the ADU. This prevents absentee landlords from owning single-family homes with ADUs on site. Although this rule might seem relatively minor, it has major financing implications, and is one of the reasons that banks are hesitant to lend on ADUs. If a bank was forced to foreclose on a property with an ADU, it would not be able to rent out both units, nor would any prospective investor. Owner occupancy rules of this sort exist in 30 of the 46 cities surveyed by Sightline and the Oregon DEQ (Durning, 2013). In addition to owner occupancy requirements, many cities enforce general occupancy limits that put a ceiling on the number of unrelated individuals who can live on a site. These rules vary widely from city to city, and therefore have differing impacts. In the city of Eugene Oregon, the number of unrelated individuals sharing a house is limited to 5; in Seattle, the limit is 8 (Durning, Decriminalizing roomates: occupancy limits, 2012). Both restrictions can present a challenge to ADU developers.

Open space requirements and unit mix regulations can prevent innovative multi-family housing, including micro-apartments. SPUR found that in San Francisco, laws unfairly penalized small units by applying the same standards that are applied to larger units (Karlinsky, Szambelan, \& Wang, 2017). In San Francisco, for example, public open space is required on a per unit basis, which inadvertently incentivizes projects to include a lower number of larger units (Gabbe, 2014). Development fees are also commonly assessed on a per-unit basis. In certain zones, San Francisco also mandates a certain percentage of units be two-bedroom units. Obviously, a community could not consist solely of microstudio apartments in these zones. Unit mix regulations like this might not have as large of a negative effect due to the market desirability of buildings with a mix of unit types.

\footnotetext{
${ }^{38}$ For a hypothetical 100-unit micro-apartment project in San Jose, base code would require 1.25 to 2 parking spaces per unit (Karlinsky, Szambelan, \& Wang, 2017). In a best-case scenario, with 1.25 parking ratio and $\$ 25,000$ per space construction costs, parking could add $\$ 3,125,000$ (\$31,250 per unit) to the total construction cost of the project. At the higher end of estimates, this parking cost grows to a staggering $\$ 10,000,000$ ( $\$ 100,000$ per unit).
} 
Table 2: Zoning restrictions on ADU construction

\begin{tabular}{|l|l|}
\hline Restriction & Effect on ADUs \\
\hline Density & Can outright ban ADUs in low-density zones \\
\hline Parking & $\begin{array}{l}\text { Greatly increases cost of construction; renders construction } \\
\text { impossible on many single-family lots which lack room for off } \\
\text { street parking. Dictates where on site the ADU can be built }\end{array}$ \\
\hline Lot size & $\begin{array}{l}\text { Minimum lot size requirements outright forbid ADU construction } \\
\text { on many smaller lots which could still physically fit an ADU. }\end{array}$ \\
\hline Unit size & $\begin{array}{l}\text { Maximum unit size for ADUs are often dictated as a percentage of } \\
\text { the size of the primary residence. When the primary residence is } \\
\text { small, these rules can require ADUs to be too small to function. }\end{array}$ \\
\hline Owner occupancy & $\begin{array}{l}\text { Many jurisdictions require that the owner of the lot either occupy } \\
\text { the ADU or occupy the primary residence. This discourages } \\
\text { investors (who might be more likely to have the initial capital } \\
\text { required for construction) from building ADUs and limits the resale } \\
\text { of these houses with ADUs to investors. This can also impact a } \\
\text { bank's willingness to lend, as a bank foreclosing on an ADU would } \\
\text { not be able to rent the units out. }\end{array}$ \\
\hline Open space & N/A for ADUs \\
\hline Unit mix & \multicolumn{1}{|l}{ N/A for ADUs } \\
\hline
\end{tabular}

Table 3: Zoning restrictions on micro-apartment construction

\begin{tabular}{|l|l|}
\hline Restriction & Effect on micro-apartments \\
\hline Density & $\begin{array}{l}\text { This can reduce the total number of buildable units below the } \\
\text { threshold required to make a project financially viable }\end{array}$ \\
\hline Parking & $\begin{array}{l}\text { These rules add considerable expense, which might not be financially } \\
\text { viable and will likely raise rents. These rules might not consider that } \\
\text { the parking needs of a micro-apartment building might be different } \\
\text { than the parking needs of conventional apartments. Physical } \\
\text { construction of parking might not be possible given lot size } \\
\text { constraints. }\end{array}$ \\
\hline Lot size & N/A for micro apartments. \\
\hline Unit size & $\begin{array}{l}\text { Many cities have minimum unit sizes, which prevent micro- } \\
\text { apartments from being micro in the first place. Some cities also have } \\
\text { requirements for minimum room sizes which can cause challenges } \\
\text { when laying out micro-apartment floorplans. }\end{array}$ \\
\hline Owner occupancy & $\begin{array}{l}\text { N/A for micro apartments. } \\
\text { If a city requires open spaces tied to unit count, the provision of } \\
\text { adequate open space can be prohibitive given the vast number of } \\
\text { units in micro-apartment projects. A micro-unit building of equivalent } \\
\text { square footage as a conventional apartment building would be } \\
\text { required to have more public space. }\end{array}$ \\
\hline Open space & $\begin{array}{l}\text { Some jurisdictions require a certain percentage of units to have more } \\
\text { bedrooms, with the logic being that developers will undersupply } 2 \\
\text { and 3-bedroom units otherwise. This can prevent a project from } \\
\text { being entirely micro. }\end{array}$ \\
\hline Unit mix &
\end{tabular}


While many of these codes influence AHTs in unintended ways, at least some of the regulatory challenges to small housing are intentional. A number of jurisdictions that claim to allow ADUs have utilized building codes as a form of "passive resistance" to circumvent ADU production (Brinig \& Garnett, 2013). In the state of California, where cities are required to permit ADUs, this passive resistance allows cities to avoid the state's imperative. Municipal opposition to AHTs likely rises out of the neighborhood resistance described in the preceding section of this paper. As an example, after neighborhood objections against micro-apartment construction in Seattle, the city implemented several code changes which effectively banned this type of small housing. ${ }^{39}$

\section{The Case for a New Housing Paradigm}

As shown, the arguments in favor of AHT housing are numerous. Regardless of the theoretical and actual benefits of smaller housing, production is relatively small and strong opposition remains. In order to move towards a new housing paradigm where smaller units make up an increased proportion of housing construction, jurisdictional and institutional changes will be necessary. The positive aspects of small housing suggest that this change could create societal gain. Although cities looking at AHTs might not choose to actively promote this type of development, it is incumbent on responsible jurisdictions to adopt policies that treat small units fairly and reduce unnecessary barriers. Below, a three-pronged approach is recommended to foster AHT development.

First, the lack of research on the subject of AHTs continues to serve as a barrier. Urban jurisdictions, budget-strapped as they are, are unlikely to undertake the necessary research themselves. Cities can contribute positively to a greater understanding of AHTs by keeping databases of where these units exist. This will empower scholars to continue to expand on AHT research. Banks and other institutions will need to undertake their own due diligence when it comes to AHT performance. As the absolute number of successful micro-apartment projects continues to grow, so too should bank and appraiser interest in these properties.

Second, public information campaigns should be deployed to increase consumer understanding of small units. Providing accurate information on the benefits of density and the advantages of small units will hopefully assuage some opposition of AHT projects. Chapple, Wegmann, Mashhood, \& Coleman found that "learning about ADUs through an educational website, event or tour" was one of the top three factors motivating homeowners to initiate ADU construction (2017 p. 19). Urban jurisdictions can be the ones who promote this material; the job of education can also fall upon urban think tanks and universities. ${ }^{40}$ As suggested by Chapple et al. (2017), even informational websites and tours can be an effective tool for ADU promotion. Information provided by cities about ADU development can be helpful in guiding builders though the permit process; ADU development is complicated and many homeowners do not know what to do (Brown M. J., 2014).

\footnotetext{
${ }^{39}$ For more, see "How Seattle Killed Micro-Housing" (Neiman 2016) and "How Seattle Killed Micro-Housing Again" (Neiman 2017).

40 Portland, OR and Santa Clara, CA are cities who have helped propagate information about AHTs; SPUR and the Sightline Institute are think tanks which have promoted AHTs, and Portland State University is a University that has been an active AHT booster.
} 
Perhaps the most important way to encourage AHT construction is to modernize regulatory policy, which often unfairly penalizes small development. For cities facing affordability crisis, this work carries the potential to provide affordable units without an outlay of public subsidy. Even cities that do not have rapidly raising housing costs can benefit from the increased density, the environmental benefits, and diversity of housing options provided by AHTs. As long as neighborhood objections are addressed in a logical way based on academic research, the provision of more AHT housing seems unlikely to lead to negative side effects. For cities looking to implement more size-neutral codes, the adoption of a standard model AHT code has been suggested. ${ }^{41}$ Easing land use rules was cited by-far as the top factor leading homeowners to build an ADU (Chapple et al. 2017).

The public sector has an essential role to play in creating an environment where the private and nonprofit sectors can effectively meet the nation's housing challenges. Regulations at the federal, state, and local levels that affect construction and financing define what types of housing can be built and where. There are valid concerns that the regulatory environment has grown overly restrictive and has contributed to today's shortage of affordable homes. But addressing these concerns requires balancing the legitimate public benefits of regulation against their costs (Joint Center for Housing Studies, 2017, p. 37)

It is the belief of this author that AHTs are no passing fad. Given the cultural and economic changes facing $21^{\text {st }}$ century America, small housing seems to be a natural evolution in urban living. Faced with this impending change, cities and urban residents have a choice: they can resist AHTs, maintaining the status quo and preventing the benefits of small housing from being realized, or they can embrace the change, and work to maximize potential benefits. By studying successful small housing case studies, cities can weigh the benefits of AHTs against possible negative externalities and develop a plan of action to address neighborhood opposition and institutional unfamiliarity in an equitable way. Small housing is a big idea, and collaboration will be necessary to unlock its full potential. This paper hopes to serve as a call to action, encouraging cities, universities, developers and the greater public to engage in a conversation about alternative housing typologies.

\footnotetext{
${ }^{41}$ The disorganized and chaotic tangle of local regulations prevents standardization and economies of scale in AHT (especially ADU) development. The AARP, with the assistance of the American Planning Association, surveyed existing ADU regulations and case law in order to create a draft state and local ADU enabling ordinance (Cobb \& Dvorak, 2000). These ordinances can serve as a useful model for governments looking to adopt regulation that is ADU-positive. The AARP report containing the ordinances as well as survey methodology can be accessed online: https://assets.aarp.org/rgcenter/consume/d17158_dwell.pdf
} 


\section{Bibliography}

Abel, J. R., Dey, I., \& Gabe, T. M. (2011). Productivity and the Density of Human Capital. Journal of Regional Science, 52(4), 562-586.

Been, V., Gross, B., \& Infranca, J. (2014). Responding to Changing Households: Regulatory Challenges for Micro-Units and Accessory Dwelling Units . New York: NYU Furman Center .

Benjamin, G. C., \& Vernon, T. M. (2014). The National Healthy Housing Standard. The American Public Health Association.

Bertolet, D. (2017, October 31). Musical Chairs (Or why is rent so high?). Retrieved from The Sightline Institute.

Brinig, M. F., \& Garnett, N. S. (2013). A Room of One's Own: Accessory Dwelling Unit Reforms and Local Parochialism. Urban Lawyer, 45, 519-569.

Brown, M. J. (2014). Accessory dwelling units in Portland, Oregon: evaluation and interpretation of a survey of ADU owners. Portland: Oregon Department of Environmental Quality.

Brown, M. J. (n.d.). Accessory dwelling units: what they are and why people build them. Retrieved from Accessorydwellings.org: https://accessorydwellings.org/what-adus-are-and-why-people-buildthem/

Brown, M. J., \& Watkins, T. (2012). Understanding and appraising properties with accessory dwelling units. The Appraisal Journal, Fall, 297-308.

Carmiel, O. (2013, January 22). Manhattan to Get First 'Micro-Unit' Apartment Building. Bloomberg .

Chan, S., \& Gould, E. I. (2017). Housing for an aging population. Housing Policy debate, 27(2), 167-192. doi:http://dx.doi.org/10.1080/10511482.2016.1184696

Chapman, N. J., \& Howe, D. A. (2001). Accessory Apartments: Are They a Realistic Alternative for Ageing in Place? Housing Studies, 16(5), 637-650.

Chapple, K., Wegmann, J., Mashhood, F., \& Coleman, R. (2017). Jumpstarting the market for accessory dwelling units: Lessons learned from Portland, Seattle and Vancouver. San Francisco: The Urban Land Institute.

Chapple, K., Wegmann, J., Nemirow, A., \& Dentel-Post, C. (2011). Yes in My Backyard: Mobilizing the Market for Secondary Units. Berkeley : Center for Community Innovation, UC Berkeley.

City of Portland. (n.d.). Small homes go big: Accessory Dwelling Unit (ADU) development soars in Portland. Retrieved from Bureau of Planning and Sustainability :

https://www.portlandoregon.gov/bps/article/484726

City of San Francisco . (2013, January 07). New Planning Code Summary. Efficiency Dwelling Units: Numerical Cap and Open \& Common Space Requirements. City of San Francisco Planning Department.

City of Seattle. (2017, May 04). Director's Rules 9-2017. Small Efficiency Dwelling Units. City of Seattle Department of Construction and Inspections. 
Cobb, R. L., \& Dvorak, S. (2000). Accessory dwelling units: model state act and local ordinance . Washington : AARP Public Policy Institute .

Davis, E. (2017, May 22). WDC Sells Freemont Apts in Portland. CoStar News.

Drier, P. (1982, December). The Status of Tenants in the United States. Social Problems, 30(2), 179-198.

Durning, A. (2012, December 10). Decriminalizing roomates: occupancy limits. Retrieved from The Sightline Institute.

Durning, A. (2013, March 15). ADUs and don'ts . Retrieved from The Sightline Institute.

Environmental Protection Agency. (2013). Sustainable Design and Green Building Toolkit for Local Governments. US EPA.

Environmental Protection Agency. (2014). Smart growth and economic success: investing in infill development. Washington: U.S EPA.

Ewing, R., Pendall, R., \& Chen, D. (2003). Measuring Sprawl and its Transportation Impacts. Transportation Research Record, 1831, 175-183.

Friedrich, A. (2004, June 21). Not just for grannies anymore. Monterey County Herald.

Gabbe, C. J. (2014, August 10). Looking through the lens of size: Land use regulations and microapartments in San Francisco. Cityscape, 17(2). Retrieved from https://ssrn.com/abstract=2478499

Gallagher, C. L., Reaser, L., Crane, Peggy, Mauerman, Dieter, ... Herbig, N. (2014). Opening San Diego's door to lower housing costs. Point Loma Nazarene University. San Diego: Fermanian Business \& Economic Institute.

Geffner, T. (2017, August). Land Use Zoning in America: The Case for Inclusionary Policy. Anthos, 8(1).

Glaeser, E. L., \& Gyourko, J. (2002). The Impact of Zoning on Housing Affordability. National Bureau of Economic Research.

Gleim, L. (2017, March 28). Maps show 30 percent of Portland homes could host backyard homes. Retrieved from Portland State Sustainability: https://www.pdx.edu/sustainability/solutionsblog/maps-show-30-percent-of-portland-lots-could-host-backyard-homes

Green, P. (2016, June 10). Tiny Home Test Drive? The New York Times.

Gyourko, J., Mayer, C., \& Sinai, T. (2013). Superstar cities. American Economic Journal: Economic Policy, 5(4), 167-99.

Holden, D. (2013, May 8). The Fight Against Small Apartments. The Stranger.

Infranca, J. (2016). Spaces for Sharing: Micro-Units amid the Shift from Ownership to Access. Fordham Urban Law Journal, 43(1).

Institute for Sustainable Solutions. (2017). Small Backyard Homes: Accessory Dwelling Units (ADUs). Retrieved from Portland State Univerity Sustainability : https://www.pdx.edu/sustainability/adu 
Jacobs, J. (1961). The Death and Life of Great American Cities. New York: Random House.

Joint Center for Housing Studies. (2017). America's Rental Housing. Cambridge: Harvard University.

Joint Center for Housing Studies. (2017). State of the Nation's Housing. Cambridge: Harvard University.

Kackar, A., \& Preuss, I. (2003). Creating Great Neighborhoods: Density in Your Community. Local Govenment Commission. U.S. Environmental Protection Agency .

Karlinsky, S., Szambelan, S. J., \& Wang, K. (2017). Room for More. San Jose : SPUR .

Keenan, T. A. (2010). Home and community preferences of the $45+$ population. Washington: AARP Research and Strategic Analysis.

Kristian, B. (2017, August 4). Want to be happier? Live in a small house. The Week.

Lau, Q. (2014). Black boxes and gray spaces: how illegal accessory dwellings find regulatory loopholes. Manoa: University of Hawai'i School of Architecture.

Lipman, B., Lubell, ,. J., \& Salomon, E. (2012). Housing an Aging Population: Are We Prepared? Center for Housing Policy.

Macht, W. (2015, June 26). Developing private accessory dwellings. Urban Land .

Macht, W. (2017, November 8). Accessory Dwelling Units. (T. Geffner, Interviewer)

Menard, L. (2016, 122$)$. ADUs work for multigenerational families: the hidden values of ADUs. Retrieved from Accessory Dwellings: https://accessorydwellings.org/2016/01/22/adu-multigenerationalfamilies/

Neiman, D. (2017, March 2). How Seattle Killed Micro Housing Again. Retrieved from The Sightline Institute.

Njus, E. (2013, November 5). Micro-apartments of less than 200 square feet coming to Portland. The Oregonian.

Njus, E. (2017, April 14). Seattle, Portland lead in rising home prices. The Oregonian.

Office of Policy Development and Research. (2016). Comprehensive housing market analysis: PortlandVancouver-Hillsboro-Oregon-Washington. Housing and Urban Development.

Overbo, B., Minkler, M., \& Liljestrand, P. (1991). No room in the inn. Journal of Housing for the Elderly, 8(1), 77-92.

Panoramic Interests. (n.d.). CitySpaces. Retrieved from Panoramic Interests Web Site.

Post, R. (2014, August 25). Are tiny houses and micro-apartments the future of urban homes? The Guardian.

Rosenberg, M. (2016, July 21). Seattle Rents Now Growing Faster Than in Any Other U.S. City. The Seattle Times. 
Rosenberg, M. (2017, September 6). King county home prices surge 18 percent, most on record for this time of year. The Seattle Times.

Rudel, T. K. (1984). Household change, accessory apartments, and low income housing. The Professional Geographer, 36(2), 174-181.

Sage Computing. (2008). Accessory Dwelling Units: Case Study. Reston, VA: US Housing and Urban Development .

Solovitch, S. (2014, October 14). Scrunched in Seattle. Politico.

Sparshott, J. (2016, June 2). U.S. Houses Are Still Getting Bigger. The Wall Street Journal.

SPUR Housing Committee. (2006). Secondary Units. San Francisco : SPUR .

Stern, E., \& Yager, J. (2018). 21st Century SROs: Can small housing units help meet the need for affordable housing in New York City? . New York : NYU Furnam Center.

Strabic, M. (2016). Multifamily Market Analysis. Center for Real Estate Quarterly, 10(1).

Taylor, M. (2016). Perpectives on Helping Low-Income Californians Afford Housing. Sacramento: Office of the California Legislative Analyst.

Templeton, A. (2017, August 15). 'Granny Pods' Help Keep Portland Affordable. NPR Morning Edition.

The White House. (2016). Housing Development Toolkit.

U.S. Energy Information Administration. (2012, April 12). The impact of increasing home size on energy demand. Retrieved from Residential Energy Consumption Survey: https://www.eia.gov/consumption/residential/reports/2009/square-footage.php

Urban Land Institute . (2014). The Macro View on Micro Units.

US Housing and Urban Development. (2015). The Case for Small Home Design as a Component of Sustainability Efforts. PD\&R Edge. Retrieved from https://www.huduser.gov/portal/pdredge/pdr-edge-featd-article-080816.html

Valhouli, C. (2016, October 24). Could micro-apartments solve the affordable housing crisis? The Los Angeles Times.

Vincent, R. (2014, March 14). Whitley House in Hollywood converted to micro-apartments and sold. The Los Angeles TImes.

Watson, S. (2013, August). Time to Make Room. The Urbanist(526).

Wegmann, J. (2015). The Blocked Market for Financing Small Apartments on Residential Properties, and What the State of California Can Do About It. Institute of Governmental Studies: U.C. Berkeley. Retrieved from https://igs.berkeley.edu/sites/default/files/2015_housing_research_brief_8-2515.pdf

Wegmann, J., \& Chappel, K. (2012). Understanding the market for secondary units in the East Bay. Berkeley : Institute of Urban and Regional Development . 
Wegmann, J., Schafran, A., \& Pfeiffer, D. (2016). Breaking the Double Impasse: Securing and. Housing Policy Debate. doi:10.1080/10511482.2016.1200109

Werner, F. E., \& Brynson, D. (1982). A guide to the preservation and maintenance of single room occupancy (SRO) housing. National Clearinghouse of Legal Services, 999-1009.

Whorton, A. (2009, September 15). DADUs. Retrieved from Laurlehurst Community Club: http://www.laurelhurstcc.com/issues/Housing/DADUs.htm

Wollan, M. (2012, September 26). San Franciscans Divide Over Pint-Size Apartments. The New York Times.

Wong, M. (2015, November 02). Historic South Downtown Oral Histories: Marie Wong Discusses Her Research on Seattle's SRO Hotels and the Men and Women Who Lived in Them. Retrieved from History Link : http://www.historylink.org/File/11135

Young, B. (2015, December 19). Big interest in little backyard houses: Will Seattle ease the rules? The Seattle Times. 